\title{
The 'smugness' of geographers: Dismantling the caricatures of philosophies in human and physical geography
}

Rob Inkpen (robert.inkpen@port.ac.uk Department of Geography, University of Portsmouth, UK)

\begin{abstract}
Caricatures of physical and human geographers are both very smug; one in their belief that they have direct and practical contact with reality, the other in the belief that their range of philosophical approaches provides a more nuanced understanding of the complexities of reality. Breaking down these caricatures is essential to configuring geography as a discipline with something important to say about environmental issues facing humanity. A key role for any textbook on the philosophy of physical geography is to start to dismantle these caricatures. The textbook needs to make problematic what seems obvious; it needs to question traditional approaches, the unspoken 'canons', upon which understanding is built. Engaging physical geographers with the philosophical side needs to be done in terms that are of immediate interest particularly through the discussion of the practice of the subject. Understanding how practising physical geography is an inherently philosophical enterprise will help physical geographers understand the potential of philosophy to improve their understanding of their methods and results as well as the nature of their contact with physical reality.
\end{abstract}

Key words textbooks, canons, philosophy

\section{Disciplinary Canons and Geographical Practices}

When I started as a postgraduate discussing the philosophy of the subject prompted people to fall into two badly defined, but smug, camps. Human geographers had a diversity of philosophical positions to occupy from which they claimed to understand the complex essence of reality, whilst physical geographers either just 'got on with it' or claimed the 
objectivity of science as their route to understanding reality. Textbooks that covered philosophy through the 1980 s and 1990s were overwhelming focused on the philosophy of human geography and its flavours (e.g. Cloke et al. 1991; Gregory 1978; Holt-Jensen 1980; Johnston 1979; Kobayashi and Mackenzie 1989). , , The few textbooks focused on the philosophy of physical geography (Gregory 1985; Haines-Young and Petch, 1983) discussed empirical research and the basics of the philosophy of science. Rhoads and Thorn (1996) began to delve deeper into the philosophy of science and to make the obvious problematic which helped me to begin to see how the philosophy 'nut' in physical geography might be cracked.

The division of geography seemed odd to me given the frequent discussion about the integration of physical and human geography since 1980s (e.g. Baerwald 2010; Clifford 2002; Goudie 1986; Harrison et al. 2004; Johnston 1986)., ), a theme that has a long disciplinary history. One of my aims in writing a textbook was to tackle this apparent paucity of philosophical enquiry in physical geography, to put it on an equivalent footing to human geography for students.

With the philosophical camps of human and physical had I identified and was I opening up key canons of geography though? Are the camps real or are they a product of my context in a specific time and place? Recent debates about what a geographical canon is (Agnew, 2012; Barnes; 2015; Johnston and Sidaway 2015; Powell, 2015) ) indicate that answering these questions is not an easy task. Simplifying a complicated debate, a canon can be seen as a body of published work that is foundational to the subject that provides the template for the identity of the subject and what it does. It provides students with a guide to the culture of the subject, what questions the subject asks and how to answer them (bearing some commonalities with research programmes and paradigms).

Powell (2015) believes that canons are a dimension of identity formation with geography lacking canons. What geography does have, in his view, are traditions, ways of practicing 
the subject passed on from one generation of practitioners to the next. Whatever we call such divisions they could represent what Barnes (2015) called a 'strategic' canonization'. Barnes viewed this process as representing the need for a group to establish even a temporary identity to rally around. Given geography's almost perpetual concern with its academic status, it might be that rather than the 'free-floating' discipline Barnes envisages, human and physical geography have become tethered to different and supposedly more respected traditions and canons in the social and physical sciences. This is a vision of the divide that resists integration as both sides of the subject, like stroppy teenagers, have joined different bigger gangs.

Whilst I may not have identified a canon in the human/physical division, I think I identified a division in the subject with respect to terminology, techniques, the nature of explanation and concepts and philosophical frameworks. In the UK case with which I am most familiar, there was a division in how geography was practised between the two camps that, in retrospect, I think maybe related to their tethers to wider social and physical science traditions and practices. A clear human/physical divide may be more caricatured than is real but the division and the entrenchment of each camp is, I believe, still visible within exercises such as the UK's Research Excellence Framework (REF), and more widely the journals of choice for publication and research groups within departments. All at a time when research councils are explicitly demanding cross-cutting and interdisciplinary research.

\section{Writing Science, Philosophy and Physical Geography}

Writing a textbook is a long process and one that should not be undertaken without a career health warning. I was fortunate that I the textbook I wrote, Science, Philosophy and Physical Geography $(2005 ; 2013)$ had a three-year gestation period before I even submitted a book proposal. One of the courses I taught was a philosophy of physical geography, which colleagues were happy to leave to me to design, run workshops and lecture on. The dearth of suitable textbooks meant that I had to produce my own source material. I was also 
concerned that the course not sit in isolation from the rest of the curriculum. I wanted to use philosophy to question, not only the nature of physical geography, but the assumptions upon which human and physical geographers seem to divide, the assumptions of objectivity of science and the central role of the process of investigation. The preface outlines the key themes I wanted to consider in the textbook - what is the reality studied, what are the things that are the focus of study and why these, what counts as valid explanation and how do physical geographers engage with this reality? Using these philosophical questions as the starting point I then wanted to build up a foundation for students to debate these questions and to believe that they could formulate their own answers.

Bold as these themes might seem, the process of teaching, feedback and refinement of the building blocks of the course suggested that understanding and applying the concepts were not beyond undergraduates. Engagement, understanding and application depended on translating concepts into practical examples that dovetailed with the undergraduate experience and material from more 'traditional' physical geography units that they were taught at the same time. It also depended upon the dynamic debate stimulated from workshops. From this base it was possible to engage students in philosophical debates about the nature of geography and by so doing begin to break the caricatures of 'physical' and 'human' geography as being so different. Both understood reality through a process of investigation, both had claims about what counted as evidence and explanation and both had assumptions at their core that needed to be articulated and questioned.

Writing a textbook is a process of continual negotiation. Negotiation with the students taking the course to find out what works and what doesn't, negotiation with a co-author to ensure a consistent argument throughout the book and negotiation with publishers who responded to market needs and market feedback. Negotiation is a good thing. It is essential in shaping the discussion and ensuring that as wide an audience as possible is interested in the textbook. This is particularly the case with the involvement of a co-author on the second edition, 
Graham Wilson, who ensured that the textbook covered key areas of physical geography and that the language and tone was appropriate to the intended undergraduate audience. Yet rather than the process of negotiation, I increasingly felt that the nature of the textbook itself eroded the ideals of leading students through and challenging the canons, or rather the traditions, of the subject. Sidaway and Hall (2017) point out the potential impact of the norms and economies of publishing which undoubtedly had an impact on mine and every other textbook produced. It is unavoidable that a paper textbook is a material, static product that freezes the evolving thoughts of the author. The content of a philosophy textbook emerged from discussion and yet this becomes a one-way dialogue when in printed form. Any feedback is slow, often shrouded in politeness (or not) and far too late to inform the inert debate in the textbook. Once released the textbook itself become an almost independent actant in different teaching networks, taking on unintended constraining roles and purposes for lecturers and readers.

An example of this constraining of the bold objective of trying to enable students to think through the philosophical questions is illustrated by the development of boxed illustrations of the questions in practice. Although a useful guide to understanding, these boxes increasingly became a focus for students in preparing for examinations and essays. The illustrations became the concepts and application beyond these illustrations became difficult to achieve. For the students, the initially wide ranging linking of the philosophical questions to their other classes taught at Portsmouth contracted to the 'easy' examples in the textbook. My guess is that this contraction is a common phenomenon. Student feedback may have helped refine the illustrations to ensure their comprehension but it may have also ossified the concepts and philosophical debates as being these illustrations. By its nature as a static, one-way dialogue, the textbook will fail to develop the debate and questioning that philosophical consideration of the subject demands to break down the human/physical divide. I may wish the goal of the textbook to be to engender and encourage questioning but the inert and the 
supposedly authoritative nature of the textbook mitigates against this goal as soon as the textbook is produced.

The seeming continuation of the two camps suggests that my textbook hasn't been able to do much to overcome wider barriers to integration. Its basis for courses in the philosophy of physical geography immediately means human geographers are unlikely to read it, perpetuating the divide. There are encouraging signs of an interest in critical physical geography (Allen and Lukinbeal 2011; Blue and Brierley 2016; Brierley et al. 2013) tackling philosophical issues in physical geography including a special edition of Progress in Physical Geography (Lave 2015), but it is difficult to attribute this to textbooks rather than a context and individuals that now seek to encourage such thinking. It may mean, however, physical geographers, with tongues set firmly in cheeks, can now be 'smug' in a different way as they can now do 'human' geography.

\section{Acknowledgements}

My thanks to all the undergraduates who endured or enjoyed my philosophy of physical geography unit, to the colleagues who discussed the unit with me over the years of its existence, to the reviewers of the original book proposal and my special thanks to my coauthor on the second edition, Graham Wilson, who spoke more sense than I may have admitted. Finally, an enormous thank you and my gratitude to Andrew Mould at Routledge for commissioning and seeing the book through to completion and the countless people at Routledge who eased the publication process.

\section{References}

Agnew J 2012 Of canon and fanons Dialogues in Human Geography 2 321-323

Allen C D and Lukinbeal C 2011 Practicing physical geography: an actor-network view of physical geography exemplified by the rock art stability index Progress in Physical 
Barnes T J 2015 Afterword: strategic canonization? Journal of Historical Geography 49 9495

Baerwald T J 2010 Prospects for geography as an interdisciplinary discipline Annals of the Association of American Geographers 100 493-501

Blue B and Brierley G 2016 'But what do you measure?' Prospects for a constructive critical geography Area 48 190-197

Brierley G Fryirs K Cullum C Tadaki M Huang H Q and Blue B 2013 Reading the landscape: Integrating the theory and practice of geomorphology to develop place-based understandings of river systems Progress in Physical Geography 37 601-621

Clifford N J 2002 The future of geography: when the whole is less than the sum of its parts Geoforum 33 431-436

Cloke P J Philo C and Sadler D 1991 Approaching Human Geography Chapman, London Goudie A S 1986 The integration of human and physical geography Transactions of the Institute of British Geographers NS 11 454-458

Gregory D 1978 Ideology, Science and Human Geography Hutchinson, London Gregory K 1985 The Changing Nature of Physical Geography Hodder Arnold, London Haines-Young R and Petch J 1983 Physical geography: its nature and methods Harper and Row, London

Harrison S Massey D Richards K Magilligan F J Thrift N and Bender B 2004 Thinking across the divide: perspectives on the conversations between physical and human geography Area 36 435-442

Holt-Jensen A 1980 Geography - History and Concepts Sage, London Inkpen R J 2005. Science, Philosophy and Physical Geography Routledge, London Inkpen R J and Wilson G 2013 Science, Philosophy and Physical Geography (second edition) Routledge, Abingdon

Johnston R 1979 Geography and Geographers: Anglo-American Human Geography Since 1945 Edward Arnold, London 
Johnston R J 1986 Four fixations and the quest for unity in geography Transactions of the Institute of British Geographers 11 449-453

Johnston R and Sidaway J D 2015 Have the human geographical can(n)ons fallen silent; or where they never primed? Journal of Historical Geography 49 49-60

Kobayashi A and Mackenzie S 1989 Remaking Human Geography Unwin Hyman, Boston Lave R 2015 Introduction to special issue on critical physical geography Progress in Physical Geography 39 571-575

Powell RC 2015 Notes on a geographical canon? Measures, models and scholarly enterprise Journal of Historical Geography 49 2-8

Rhoads B L and Thorn C E 1996 The Scientific Nature of Geomorphology John Wiley and Sons, Chichester

Sidaway J D and Hall T 2017 Geography Textbooks, Pedagogy and Disciplinary Traditions Area, this issue 
